\title{
Role of histamine in the aetiology of byssinosis. II Lung histamine concentrations in guinea pigs chronically exposed to cotton and flax dusts
}

\author{
M H NOWEIR, H M ABDEL-KADER, AND A MAKAR \\ From the High Institute of Public Health and the Faculty of Pharmacy, University of Alexandria, Egypt
}

ABSTRACT Data presented in this study support the finding that cotton and flax dusts contain agents which potentiate the formation or accumulation of histamine or both in the lungs of guinea pigs exposed to dust, and that such agents are present at much higher levels in cotton dust than in flax dust. The potentiating effect may be through the recruitment of mast cells into the lung. Both cotton and flax dusts contain methylating enzyme inhibitory agents, whereas cotton dust also contains agents that inhibit histaminase activity; flax dust contains agents potentiating histamine activity. These agents working together result in the accumulation or depletion of histamine observed in the different groups of animals exposed to either cotton or flax dust in this study.

In a previous report ${ }^{1}$ a significant increase in blood histamine concentrations was shown in workers exposed to cotton or flax dust, even if they were free from any respiratory complaint. It has been suggested that the formation or accumulation or both of histamine may be potentiated by agents present in cotton dust at higher concentrations than in flax dust, and that this potentiating effect progresses at a rapid rate during early exposure but later slows down. It has been proposed that such a potentiation might explain the mechanism by which the propagation of the chronic effect of dust exposure proceeds in cotton and flax workers. The histamine accumulated in the lung over the weekend is released on exposure to dust, causing the symptoms of byssinosis. The difference in the rate of histamine metabolism relative to the rate of histamine formation in byssinotic subjects has been suggested to lead to more prolonged histamine accumulation in byssinotic subjects than in symptom free subjects, with the consequent appearance of the symptoms of byssinosis.

The present work was conducted to study the formation, accumulation, release, and metabolism of histamine in the lungs of experimental animals chronically exposed to cotton and flax dust, in order to support or discount these suggestions. The hypothesis is that exposure to dust will potentiate

Received 1 November 1982

Accepted 6 December 1982 the formation or accumulation or both of histamine in the lungs, especially during the first few months of exposure. The pattern of histamine release into, or uptake from, the blood (or both), and of histamine catabolism will determine the extent of histamine accumulation in the lungs during the exposure periods and the weekend interruption.

\section{Methods and materials}

Male guinea pigs, $390-450 \mathrm{~g}$ in weight, were obtained from the breeding colony of the Ministry of Health in two separate batches for the two experiments. The animals were kept under observation for two weeks before starting the experiment. Exposure to cotton dust was performed from May to October and exposure to flax dust from November to April. All animals were fed and given water ad libitum throughout the whole experiment.

For each type of exposure the animals were sent in cages in groups of five to the carding departments of either a cotton or a flax textile mill located in Alexandria, where they were exposed to dust. The concentration of "inhalable" dust during the whole period of exposure ranged from 0.75 to $0.95 \mathrm{mg} / \mathrm{m}^{3}$ in the cotton carding operations and from 4.4 to $9.2 \mathrm{mg} / \mathrm{m}^{3}$ in the flax carding operations (MH Noweir, in preparation). Exposure continued for seven hours during the morning shift (7 am-2 pm) for six days a week. 
In each experiment another group of 30 animals was kept in the animal house of our laboratory throughout the study period; they were similarly fed and kept under conditions similar to those of the exposed animals except for the dust exposure.

The animals were killed in groups after the fourth, twelfth, and twenty fourth weeks of exposure. For each group of animals, half were killed after the last exposure of the stated week, and half after a weekend (Friday) rest of 40 hours. In the flax dust experiment the whole group of animals exposed for four weeks was killed immediately after the end of the four week exposure period.

The following tests were performed on each animal (five in each killing):

\section{Measurement of tissue histamine content}

Histamine was determined in the lung and liver, using the method developed by Michaelson and Coffman $^{2}$ as modified by Anton and Sayre. ${ }^{3}$

\section{Measurement of the histamine catabolising activity of lung tissue}

This measurement was performed on animals that had been exposed to dust for 24 weeks. The method used was a modification of the procedure described by Bennet. ${ }^{4}$ After death the contents of the thorax were exposed through a midline incision. The lungs were rapidly removed from the trachea, chilled in ice-cold Tyrode solution, and then washed several times in the cold Tyrode to remove blood; they were then blotted on a filter paper and rapidly weighed.

A $10 \% \mathrm{w} / \mathrm{v}$ homogenate of lung tissue in Tyrode was prepared from part of the lungs of each animal using a motor driven glass homogeniser. The temperature during homogenisation was kept at $0-4^{\circ} \mathrm{C}$ by immersing the homogeniser in an ice bath.

The incubation mixture for assessment of enzyme activity contained $2 \mathrm{ml}$ homogenate, $200 \mu \mathrm{g}$ histamine acid phosphate (National Biochemicals Corporation, USA) as a substrate, and, when aminoguanidine was to be included in the incubation mixture, it was added so that its final concentration was $10^{-2} \mathrm{M}$. The total volume was then made up to $5 \mathrm{ml}$ with Tyrode solution.

Suitable blanks were run together with the experimental flasks where perchloric acid $(5 \mathrm{ml}, 0 \cdot 8$ $\mathrm{N})$ was added immediately after mixing the incubation mixture constituents before starting the incubation procedure.

The flasks were incubated at $37^{\circ} \mathrm{C}$ for 90 minutes in a thermostatically controlled water bath. The reaction was stopped by the addition of $5.0 \mathrm{ml} 0.8 \mathrm{~N}$ perchloric acid. The flasks were then centrifuged for 15 minutes at $300 \mathrm{rpm}$. The supernatant was separated and its histamine content was assayed as described above.

Measurement of histamine decarboxylase activity of lung tissue

A $20 \% \mathrm{w} / \mathrm{v}$ lung tissue homogenate was prepared from a similar part of the same lung using phosphate buffer $(0.1 \mathrm{M}, \mathrm{pH} 6.8)$ as the homogenisation medium. The incubation medium contained $1 \mathrm{ml}$ homogenate, histidine (Eastman Organic Chemicals, USA) $3.22 \times 10^{-4} \mathrm{M}$ and pyridoxal phosphate (Sigma) $4 \times 10^{-5} \mathrm{M}$. The volume was made up to 5 $\mathrm{ml}$ using the phosphate buffer. The incubation procedure, the stopping of the enzyme reaction, and the assessment of the formed histamine were carried out as described above.

\section{Results}

HISTAMINE CONTENTS IN ANIMALS EXPOSED TO COTTON AND FLAX DUST

Figure 1 shows the histamine contents in the lungs of the animals exposed to cotton and flax dusts. Histamine contents were significantly higher in the lungs of the animals exposed to cotton dust than in their controls $(p<0.01)$; the lung histamine concentration of the animals exposed for four, 12, and 24 weeks was $335 \%, 690 \%$, and $210 \%$ that of the controls. Lung histamine contents were significantly $(p<0.05)$ lower in the animals killed after a 16 hour rest at the end of the twelfth week than in those killed immediately.

By contrast, the lung histamine contents were significantly lower in the animals exposed to flax than in the controls. The mean concentrations of lung histamine in the animals exposed for four, 12, and 24 weeks were $24 \%, 15 \%$, and $23 \%$ of those of the corresponding controls. Moreover, it may be noted that the lung histamine contents of the control animals for the flax dust experiment at the fourth and twelfth weeks of the experiment were almost double ( 1.9 and 2.4 times) those of the controls for cotton dust exposure. The lung histamine concentrations were significantly higher in the animals killed after a 16 hour rest than in those killed immediately after exposure.

The changes observed in liver histamine concentrations more or less paralleled those of the lungs but the magnitude of the changes was much less in the liver and insignificant in many of the subgroups.

HISTAMINE CATABOLISING ENZYME ACTIVITY IN THE LUNGS

The effect of exposure to cotton dust and to flax dust for 24 weeks on histamine catabolising enzyme activity is shown in the table and fig 2 . In the animals exposed to cotton dust the lung histamine catabolis- 


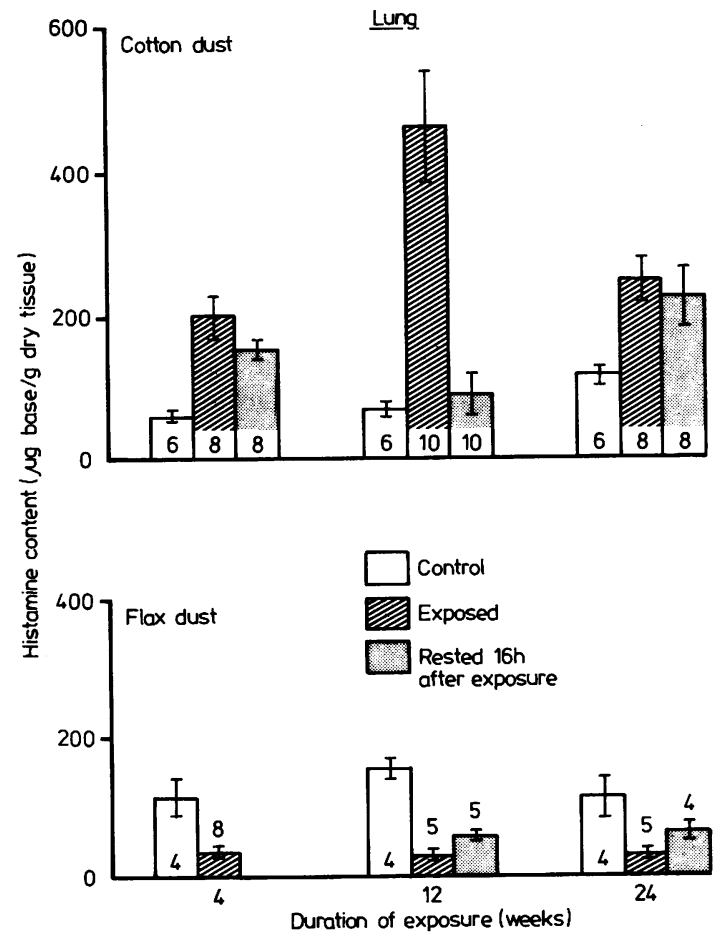

Fig 1 Histamine content in lungs of guinea pigs exposed to cotton or flax dust for different durations compared with histamine content in lungs of control animals.

ing activity (in the absence of aminoguanidine) completely disappeared after exposure, but reappeared after rest. Although the enzyme activity in the "rested" animal was lower than in the control group, the difference was not statistically significant. The same picture was observed in the presence of aminoguanidine; however, the enzyme activity in the "rested" animals was significantly lower $(\mathrm{p}<$ 0.05 ) than in the control group. It is to be noted that the addition of aminoguanidine decreased the

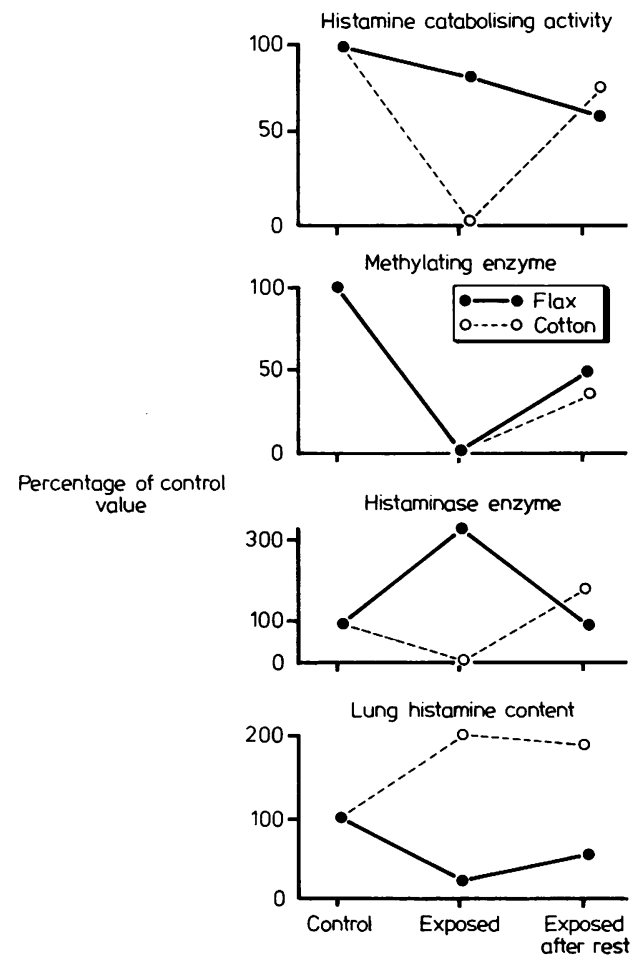

Fig 2 Change in histamine catabolising enzyme activity in relation to lung histamine content in guinea pigs exposed to flax or cotton dust.

enzyme activity in both control and "rested" groups; the decrease was statistically significant in the case of the "rested" animals $(p<0.01)$, but not in the control animals.

In the animals exposed to flax dust the level of histamine catabolising activity in the lungs (in the absence of aminoguanidine) was slightly higher than in the controls. Further reduction was observed after one day of rest; however, none of the differences between the exposed and control animals was statis-

Effect of exposure to cotton and flax dust on histamine catabolising enzyme activity in guinea pig lungs. Figures in parentheses are the number of animals used for each assessment

\begin{tabular}{|c|c|c|c|c|c|}
\hline & \multicolumn{5}{|c|}{$\begin{array}{l}\text { Histamine catabolising activity } \\
\text { ( } \mu g \text { histamine diphosphate metabolised/g tissue/90 minutes) } \\
\text { (Mean } \pm S D)\end{array}$} \\
\hline & \multirow[t]{2}{*}{ Control } & \multicolumn{2}{|c|}{ Cotton dust exposure } & \multicolumn{2}{|c|}{ Flax dust exposure } \\
\hline & & $A f t$ & After $40 \mathrm{~h}$ rest & After last expo & After $40 \mathrm{~h}$ rest \\
\hline $\begin{array}{l}\text { Aminoguanidine absent } \\
\text { Aminoguanidine present }\end{array}$ & $\begin{array}{l}359 \cdot 6 \pm 34 \cdot 0 \\
(4) \\
264.6 \pm 65.2 \\
(5)\end{array}$ & $\begin{array}{l}0.0 \\
(5) \\
0 \cdot 0 \\
(4)\end{array}$ & $\begin{array}{l}280 \cdot 0 \pm 45 \cdot 2 \\
(5) \\
100 \cdot 0 \pm 17 \cdot 5 \\
(5)\end{array}$ & $\begin{array}{l}307 \cdot 3 \pm 56 \cdot 8 \\
(4) \\
0 \cdot 0 \\
(4)\end{array}$ & $\begin{array}{l}244 \cdot 9 \pm 69 \cdot 5 \\
(4) \\
132 \cdot 2 \pm 32 \cdot 7 \\
(4)\end{array}$ \\
\hline
\end{tabular}


tically significant. In the presence of aminoguanidine the enzyme activity was completely absent in the exposed animals and it appeared in "rested" animals at a significantly lower level than in the controls.

HISTIDINE DECARBOXYLASE ACTIVITY IN LUNGS No histidine decarboxylase activity could be detected in the lungs of any of the animals tested.

\section{Discussion}

Histamine was found to accumulate in large amounts in the lungs of guinea pigs exposed to cotton dust. The accumulation progressed at a high rate during the first period of exposure, reaching its maximum in animals killed at the twelfth week. In the animals exposed to flax dust, however, the lung histamine content was considerably lower than in those exposed to cotton dust. This occurred despite the fact that the concentration of cotton dust to which the animals were exposed was much lower than that of the flax dust $(10 \cdot 3 \%-17 \cdot 0 \%)$. It should be noted that the histamine contents observed in the animals exposed either to cotton or to flax dust depend on the rate of histamine formation or accumulation or both, the rate of uptake and release into the blood, and the rate of histamine metabolism..$^{5}$ Therefore, guinea pigs exposed to flax dust showed a depletion of lung histamine due to its release into the blood, whereas during the weekend it accumulated in the lungs. Studies conducted in this laboratory have indicated that flax dust extract released more histamine from calf lung tissue in vitro than cotton dust extract (HM Abdul-Kader, MH Noweir, in preparation). The reduction in the liver histamine of these animals over the weekend may lead to the supposition that the liver, and possibly other tissues, contribute to the accumulation of histamine in the lungs. In animals exposed to cotton dust the rate of histamine accumulation in the lungs was high, exceeding the rate of histamine release into the blood, and resulting in a high histamine content in the lung tissue. On cessation of exposure the rate of histamine formation or accumulation or both was reduced more than the rate of histamine release into the blood, leading to a reduction in lung histamine content over the weekend. The similar trend observed in liver histamine concentrations may indicate that the rate of histamine release or uptake or both between the different tissues and the blood reached some type of equilibrium in these animals during the weekend.

It is noteworthy that flax dust exposure, while having a comparatively minor effect on histamine formation or accumulation or both in the lungs of the exposed animals, by comparison with those exposed to the lower concentrations of cotton dust, nevertheless caused a significant increase in the lung weights (relative to the growth of the total body weight) and in serum sodium, as well as a significant decrease in serum potassium. Such changes were not observed in the animals exposed to cotton dust. Nevertheless, the body weights of both groups of animals, those exposed to cotton or to flax dust, were drastically reduced. ${ }^{6}$

We concluded that the data presented here substantiate the belief that cotton and flax dusts contain agents that potentiate the formation or accumulation or both of histamine in the lungs of guinea pigs exposed to dust, and that the agents are present in cotton dust at much higher concentrations than in flax dust. Such a potentiating effect may also explain the chronic effect of exposure to these types of dust, and the high histamine accumulation may be due to the potentiation of histamine formation in the lungs or to the recruitment of mast cells into the lungs. In a previous study it has been shown that cotton dust extract significantly increased the histamine forming capacity of guinea pig stomach glandular cell preparation in vitro, ${ }^{7}$ but another report $^{8}$ indicates that, although the guinea pig lung contains a great amount of histamine, there is no enzyme by which it can be produced there. The results of the present study support this latter statement. No histidine decarboxylase activity could be shown in the lungs of either the exposed or the control animals. This observation is in agreement with results obtained by other workers.' It seems likely, therefore, that the increase in the histamine content in the lung of the animals exposed to cotton dust is due mainly to the recruitment of mast cells into the lung by the agents in the dust.

The differences in the type of histamine catabolising activities in the animals exposed to cotton or to flax dust may help explain the differences observed in the lung histamine contents in these animals. Histamine is metabolised by two major pathways catalysed by the histaminase (diamine oxidase) enzyme and the methylating enzyme. ${ }^{10}$ Aminoguanidine specifically blocks the diamine oxidase " but not the histamine catabolising enzyme. Thus the slight inhibition of the enzyme activity in control animals by aminoguanidine (table) suggests that the major histamine catabolising enzyme in the guinea pig lung is the methylating enzyme. This conclusion is in agreement with the results obtained by other workers. ${ }^{412}$ The exposure of guinea pigs to flax or to cotton dust for 24 weeks, however, resulted in the complete loss of the methylating enzyme activity. Whereas it resulted in completely opposite effects as regards histaminase enzyme activity. Histaminase enzyme activity was more than tripled in the lungs of 
guinea pigs exposed to flax, whereas it reached zero in animals exposed to cotton dust (fig 2). The rest which the exposed animals experienced during the weekend resulted in a certain degree of reversal in all tested animals. The methylating enzyme activity reappeared, although it did not attain the control values and the histaminase enzyme activity was reduced to about the control values in the animals exposed to flax dust. On the other hand, this activity increased almost to double the control levels in the animals exposed to cotton dust (fig 2). Therefore, in the animals exposed to flax dust, where the histaminase enzyme activity was very high, histamine concentrations neatly decreased and as the activity of this enzyme decreased over the weekend, the lung histamine content was raised. In the animals exposed to cotton dust, on the other hand, methylating enzyme histaminase activities were zero, and this was accompanied by the accumulation of large amounts of histamine which was decreased over the weekend as these activities reappeared again.

It may thus be concluded that both cotton and flax dusts contain methylating enzyme inhibitory agents. Whereas cotton dust contains inhibitory agents for the histaminase enzyme activity, however, flax dust contains agents that potentiate such activity. These agents together with the formation or accumulation or both, of histamine activites in the lung, and the histamine release or uptake or both into the blood, led to the accumulation or depletion of histamine observed in the different groups of exposed animals.

Supported by the PL-480 agreement No 03-004-C of the USPHS (NIOSH).
Requests for reprints to: Professor Madbuli H Noweir, High Institute of Public Health, 165 Horria Avenue, Hadra, Alexandria, Egypt.

\section{References}

' Noweir MH, Abdel-Kader MH, Omran FM. Role of histamine in the aetiology of byssinosis. I Blood histamine concentrations in workers exposed to cotton and flax dusts. $\mathrm{Br} J$ Ind $\mathrm{Med}$ 1984;41:203-8.

${ }^{2}$ Michaelson IA, Coffman PZ. An improved ion exchange purification procedure for the fluorometric assay of histamine. Anal Biochem 1969;27:257-61.

${ }^{3}$ Anton AH, Sayre DF. A modified fluorometric procedure for tissue histamine and its distribution in various animals. Pharmacol Exp Ther 1969;166:285-92.

4 Bennett A. The metabolism of histamine by guinea-pigs and rat lung in vitro. Br J Pharmacol 1965;24:147-55.

${ }^{5}$ Kahlson G, Rosengren E. Biogenesis and physiology of histamine. London: Edward Arnold Publishers Ltd, 1971:17-20.

- Noweir MH, El-Gazzar R, Michiel MH, Khalil HA. Study of some haematological, biochemical and pathological changes in guinea-pigs chronically exposed to cotton dust.J Egypt Public Health Assoc 1979;54:171-94.

' Ghoneim T, El-Dakhakhny M, Noweir MH. In vitro and in vivo effects of cotton dust on the histamine forming capacity and diamine oxidase activity in rats. J Egypt Public Health Assoc 1975;50:394-407.

- Ungar G. In: Wolstenholme GEW, O'Connor CM, eds. Ciba Foundation symposium on histamine. London: Churchill Ltd, 1956:431.

9 Gadmann JH. The origin of histamine in the body. In: Wolstenholme GEW, O'Connor CM, eds. Ciba Foundation symposium on histamine. London: Churchill Ltd, 1956:285-91.

${ }^{10}$ Buffoni F. Histamine and related amine oxidases. Pharmacol Rev 1966; 18:1163-99.

" Blaschko H, Freidman PJ, Hawes R, Nilson K. The amino oxidase of mammalian plasma. $J$ Physiol (London) 1959; 145:384-404.

12 Schayer RW, Reilly MA. Histamine catabolism in guinea-pigs, rats and mice. Eur J Pharmacol 1974;25:101-7. 